\title{
Implementing and Monitoring the Use of Artificial Canopy Bridges by Mammals and Birds in an Indonesian Agroforestry Environment
}

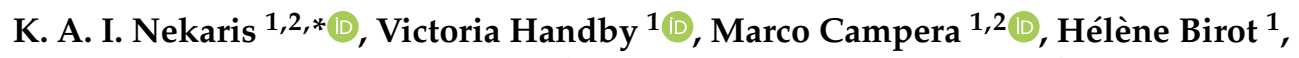 \\ Katherine Hedger ${ }^{2}$, James Eaton ${ }^{1}$ (D) and Muhammad Ali Imron ${ }^{3}(D)$ \\ 1 Nocturnal Primate Research Group, School of Social Sciences, Oxford Brookes University, Oxford OX3 0BP, \\ UK; 19032225@brookes.ac.uk (V.H.); mcampera@brookes.ac.uk (M.C.); helene.birot@yahoo.fr (H.B.); \\ james.birdtourasia@gmail.com (J.E.) \\ 2 Little Fireface Project, Cipaganti, West Java 40131, Indonesia; katey.hedger@gmail.com \\ 3 Department of Forest Resources Conservation, Universitas Gadjah Mada, Yogyakarta 55281, Indonesia; \\ maimron@ugm.ac.id \\ * Correspondence: anekaris@brookes.ac.uk
}

Received: 22 September 2020; Accepted: 13 October 2020; Published: 15 October 2020

\begin{abstract}
Deforestation is a major threat to biodiversity, particularly within tropical forest habitats. Some of the fastest diminishing tropical forest habitats in the world occur in Indonesia, where fragmentation is severely impacting biodiversity, including on the island of Java, which holds many endemic species. Extreme fragmentation on the western part of the island, especially due to small-scale agriculture, impacts animal movement and increases mortality risk for mainly arboreal taxa. To mitigate this risk in an agroforest environment in Garut District, West Java, we installed 10 canopy bridges and monitored them through camera trapping between 2017 and 2019. Five of the monitored bridges were made of waterlines and five of rubber hose. We recorded Javan palm civets using the waterline bridges 938 times, while Javan slow lorises used the waterlines 1079 times and the rubber bridges 358 times. At least 19 other species used the bridges for crossing or perching. Our results demonstrate that relatively simple and cost-effective materials can be used to mitigate the effects of habitat fragmentation. We also recommend the use of camera traps to monitor the effectiveness of these interventions.
\end{abstract}

Keywords: camera trap; palm civet; slow loris; habitat degradation; conservation evidence; deforestation; fragmentation; biodiversity

\section{Introduction}

Amongst the many causes of deforestation, agriculture and expansion of towns and cities are the greatest [1]. These activities severely fragment habitats with which biodiversity needs to survive by affecting movements of animal populations, increasing extinction risks due to population bottle necks, increasing mortality rates, increasing psychological stress, and changing home-ranges [2-5]. Indonesia's tropical forest habitats are amongst the fastest diminishing, it being one of the countries with the largest annual net loss of forest area [6]. Having already lost $90 \%$ of its natural vegetation primarily due to agriculture, Java is also characterized by a high human population, with Java accounting for $7 \%$ of the land area of Indonesia but hosting $58 \%$ of the population [6,7]. Despite this forest loss, numerous endemic species remain on the island, making it an interesting case for the potential future of other Indonesian islands [8]. One habitat type that provides a home for threatened endemic species are agroforests, which comprise approximately $17 \%$ of the agricultural land on the island [6]. The main agroforestry technique used in Java is called talun or "home-gardens," where 
plots of crops are interspersed with shrubs and other native tree species [9]. This agroforestry practice allows species to access connected habitats through a series of hedgerows, but wildlife may still have difficulty crossing croplands that lie between these rows.

There is a general consensus that wildlife corridors are an essential management strategy to mitigate the effects of fragmented habitats for arboreal mammals [10,11]. One method of connecting these fragmented habitats is through installation of artificial canopy bridges as wildlife crossings. Introducing wildlife crossings to these habitats can help achieve canopy connectivity and be a successful means of passage for various species [9,12]. Wildlife crossings typically come as either underpasses or overpasses, with the latter including ecoducts, wildlife overpasses and arboreal canopy bridges. Canopy bridges are most often used for arboreal species to connect areas of trees and may be made from rope, rubber, bamboo, poles, or waterlines $[11,13,14]$. So far, a handful of studies have quantified use of canopy bridges in species ranging from several species of primates (reviewed in [11]) to western ringtail possums Pseudocheirus occidentalis [13], kinkajous Potos flavus, brown-eared woolly opossums Caluromys lanatus and Eastern lowland olingos Bassaricyon alleni [10]. Few of these studies, however, detail the process of creating the bridges or document their use over time (e.g., [14,15]).

As part of a long-term conservation project in West Java, Indonesia, we noted early on that some species were using raised waterline or hosepipe bridges installed by farmers to irrigate crops $[7,16]$. Working with the local community through events, focus groups and conservation education, we were able to cooperate with farmers to implement and monitor additional waterlines and rubber lines on their agroforest farms. Here we describe the process of installing these bridges and examine their use by mammals and birds through analysis of camera trap data. We consider the suitability of the two bridge types for different mammal species, and their potential to be implemented in other habitats.

\section{Materials and Methods}

\subsection{Study Area}

We conducted the study in the village of Cipaganti, near the city of Garut in West Java, Indonesia [9]. The location of Cipaganti $\left(7^{\circ} 16^{\prime} 5.9^{\prime \prime} \mathrm{S}, 107^{\circ} 46^{\prime} 2.3^{\prime \prime}\right.$ E) is on the low hills of Mount Puntang, $1345 \mathrm{~m}$ above sea level. It is part of the Java-Bali montane Rain Forest ecoregion with an annual average rainfall of approximately $2500 \mathrm{~mm}$ and an average temperature of between 26 and $29{ }^{\circ} \mathrm{C}$ [7,9]. The climate is described as 'ever-wet,' and is defined as a tropical forest that experiences high annual rainfall ( $>2000 \mathrm{~mm} \mathrm{yr}^{-1}$ ) that is aseasonal [9]. The habitat is a mosaic of traditional home gardens and cultivated fields where farmers practice annual perennial crop rotation with trees interspersed around the boundary [9]. The surrounding forest habitat types include late-secondary forest, secondary forest, and forest plantations. The large-scale farming activities and undulating terrain mean some waterpipes have already been installed at a height of $12 \mathrm{~m}$ above the ground, enabling water supplies from distant ponds to irrigate fields [16].

\subsection{Artificial Bridge Construction and Monitoring}

In order to choose locations for bridges, we held focus groups with farmers who agreed to have bridges placed on their land. Between 2016 and 2019, we built the rubber bridges at a cost of $\sim \$ 40$ USD and the waterline bridges at approximately $\$ 300$ USD each (the local monthly wage is $\sim \$ 70$ USD). Farmers agreed to maintain the waterline bridges, whereas we agreed to maintain the rubber bridges, which had no economic use for the farmers. Since 2016, we installed a total of 15 bridges, 12 of which are still active in the field. The rubber bridges were created by using rubber wrapped around $1.5 \mathrm{~cm}$ width wire and waterline bridges created from 3 or $4.5 \mathrm{~cm}$ diameter water pipe tied to a wire (Figure 1). The wire proved vital for stability of the bridges and not using it resulted in the failure of seven initial bridges. When assessing where to assemble waterlines, criteria including access to a water source and a positive slope to allow the water to flow to their farms, were used. The bridges were installed by attaching the wire that is tied to the waterline or rubber, to the trees or bamboo on either side of the 
fragmented habitat. We installed rubber bridges at a mean height of $4.6 \mathrm{~m} \pm 1.4$ (SD) (range: 2-6 m) attached to trees with a mean height of $9.1 \mathrm{~m} \pm 2.2$ (range: $6-15 \mathrm{~m}$ ). We installed waterlines at a mean height of $4.2 \mathrm{~m} \pm 2.2$ (SD) (range: $1-8 \mathrm{~m}$ ) attached to trees with a mean height of $10.0 \mathrm{~m} \pm 4.2$ (range: 4-15 m). The mean length of the rubber bridges was $23.0 \mathrm{~m} \pm 17.9$ (range: 13.7-54.9 $\mathrm{m}$ ) and the mean length of the waterline bridges was $57.9 \mathrm{~m} \pm 24.6$ (range: $17.4-74.5 \mathrm{~m}$ ).
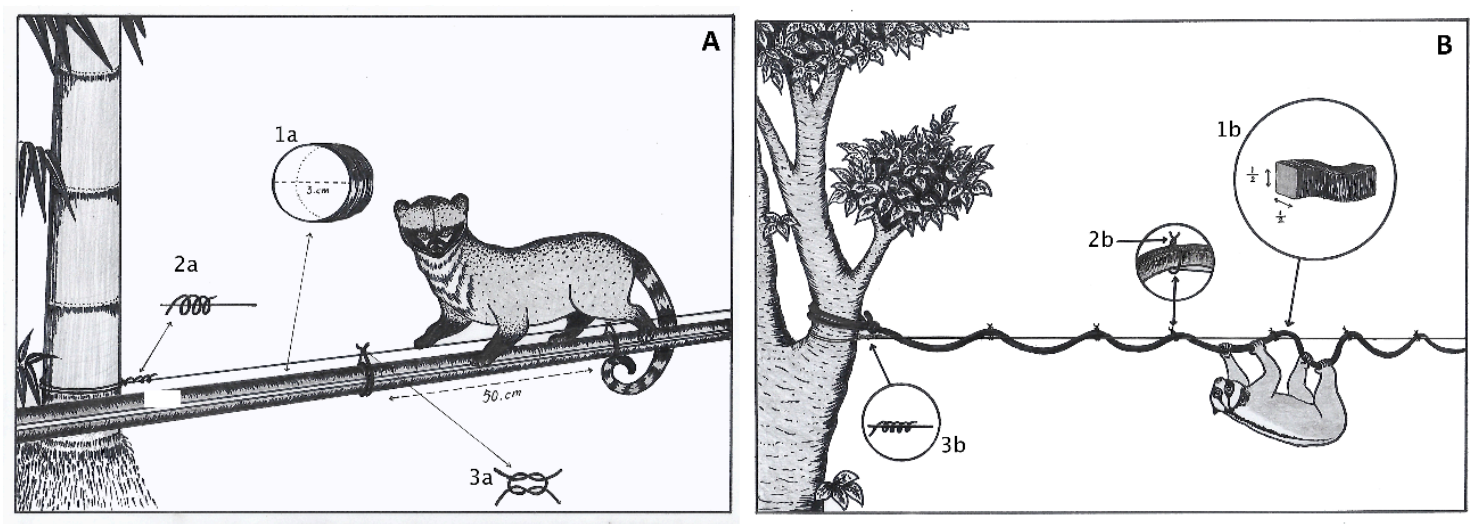

Figure 1. Diagrams of the waterline and rubber bridge designs with measurements, used in Cipaganti, West Java. (A) Diagram of a Javan palm civet using a waterline bridge. 1a: black or dark colored water hose pipe of $3 \mathrm{~cm}$ diameter; 2a: strong steel wire gauge of $1.0 \mathrm{~mm}$ for binding and stability; 3a: plastic cord to attach wire to the hose; (B) Diagram of Javan slow loris using a rubber bridge. 1b: black rubber $0.5 \mathrm{~cm}$ deep; $2 \mathrm{~b}$ : small steel wire gauge of $0.8 \mathrm{~mm}$ to bind around rubber; $3 \mathrm{~b}$ : small steel wire gauge 8 (4.1 mm circumference) to increase stability.

We set camera traps at both extremities of five waterlines and five rubber bridges on the day each bridge was installed. We used heat motion-triggered infrared cameras (Bushnell HD, model 119836, Overland Park, Kansas, USA) to monitor animal use, set up to take three photographs per capture with a 3-second delay. We swapped batteries and SD cards every 2-3 weeks. From July 2017 to December 2019, we collected data on the instances (crossing or perching) of bridge use. We considered a crossing as a single individual event (i.e., when more than one individual was on the bridge at the same time, each of them was considered as an instance of bridge use). For the two species that are the main focus of our long-term conservation project, the Critically Endangered Javan slow loris (Nycticebus javanicus), and Javan palm civet (Paradoxurus musangus javanicus, not yet included in the IUCN Red List), we describe the mean and range of the cumulative number of crossings for waterline bridges and the days of use since installation. The Javan palm civet is considered as a separate subspecies based on high genetic divergence with the other palm civets (P. musangus musangus) from the Indochinese region [17].

\section{Results}

Based on camera trap data, we detected 938 instances of use by Javan palm civets (Figure 2). These were only on waterline bridges. We found the Javan slow lorises used the waterline bridges for a total of 1079 crossings and the rubber bridges for 358 crossings. Through monitoring the bridges, we estimated the cumulative crossings of the waterline bridges for civets (Figure 3). On average, civets started using the bridges 36.2 days after implementation (range: 1-74). For the Javan slow loris we estimated the cumulative use of the waterline bridges (Figure 3). On average Javan slow lorises began to use the waterline bridges 10.4 days (range: 2-22) and the rubber bridges 15.4 days (range: 3-31) after installation.

At least 17 other species used the bridges for crossing or perching. Other mammal species using the bridges for crossing included the Least Concern Horsfield's treeshrew (Tupaia javanica, $n=259$ ) 
(both the waterline and rubber bridges) (Figure 2) and black-striped squirrels (Callosciurus nigrovittatus, $n=1$ ) (Table 1).

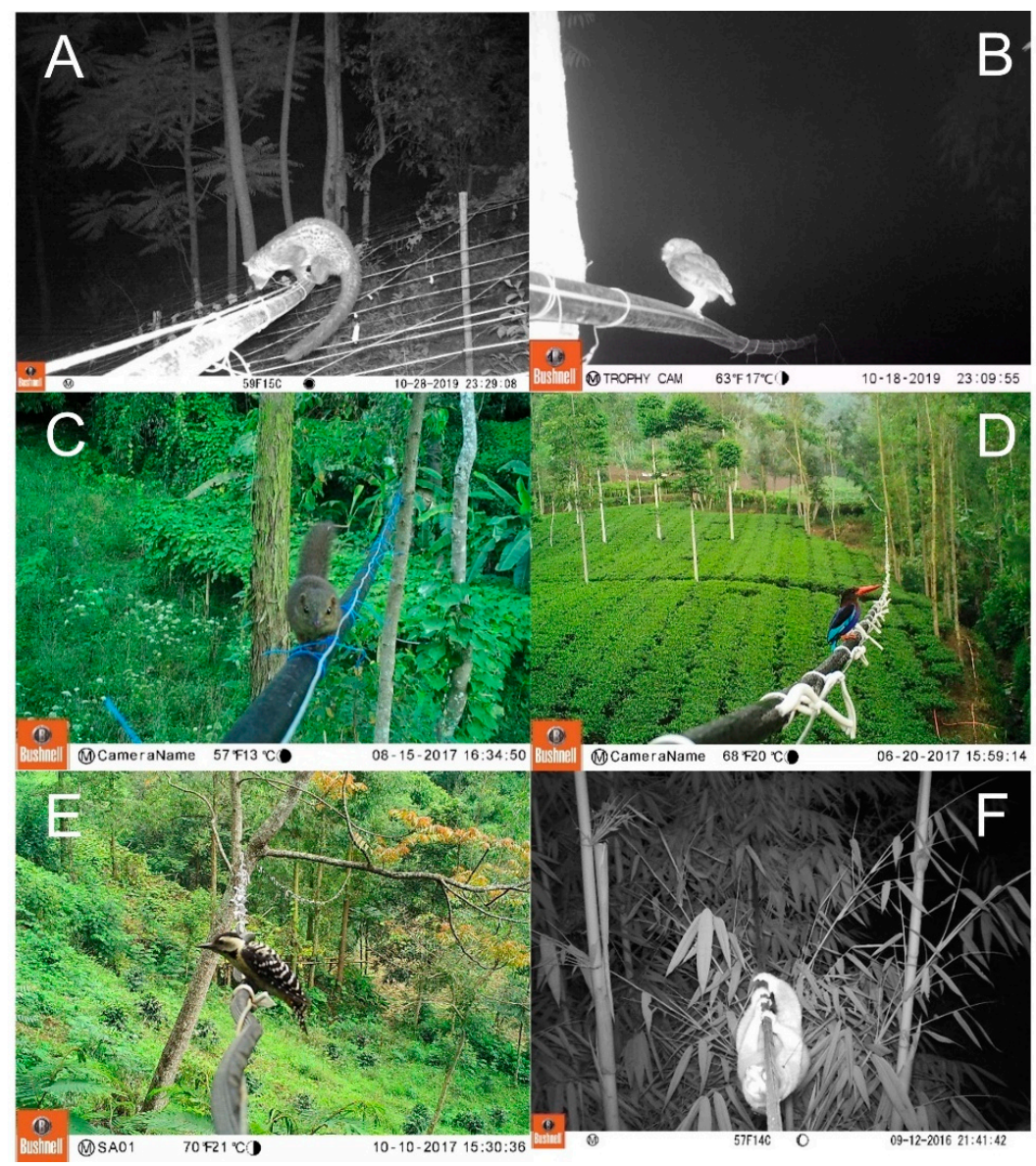

Figure 2. Camera trap images of Javan palm civet (A), collared scops owl (B), Horsfield's treeshrew (C) and Javan kingfisher (D) using a waterline bridge and freckle-breasted woodpecker (E) and Javan slow loris (F) using a rubber bridge in Cipaganti, West Java.

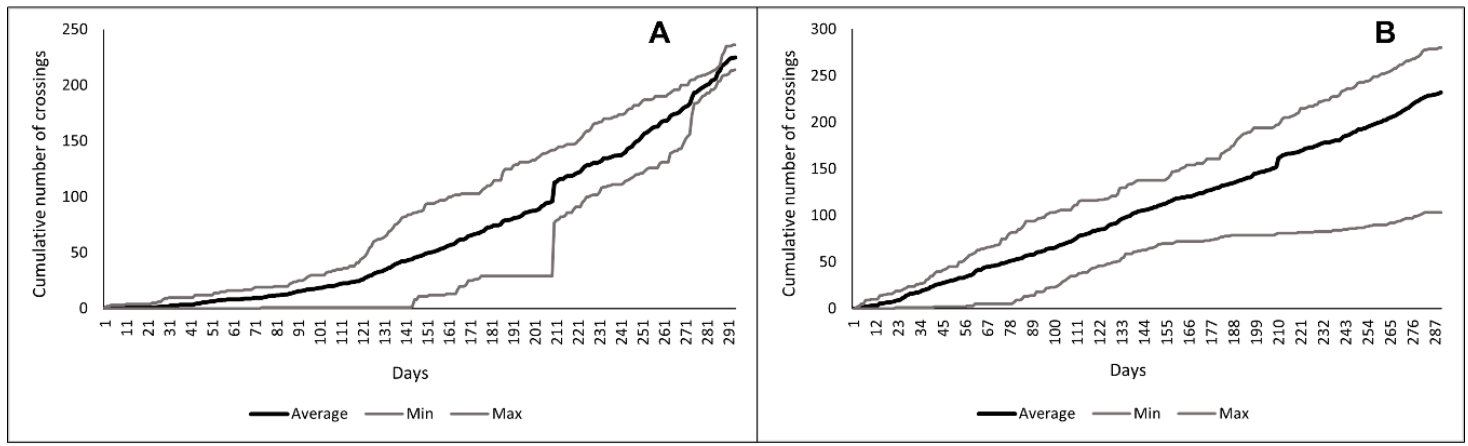

Figure 3. The average (black) and range (grey) of cumulative number of crossings on waterline bridges by the Javan palm civet (A) and the Javan slow loris (B) standardized to the days since installation for all the bridges, during the period of 2017-2019, in Cipaganti, West Java.

The Sunda leopard cats (Prionailurus javanensis, IUCN Red List status not assessed yet), the binturong (Arctictis binturong, Vulnerable), the small Indian civet (Viverricula indica, Least Concern), the banded linsang (Prionodon linsang, Least Concern), and the Javan ferret badger (Melogale orientalis, Least Concern) are known to be present in the study area but were never reported crossing bridges. 
We also documented perching by bird and bat species (Figure 2). These include, with the number of events cameras trapped, ashy drongo (Dicrurus leucophaeus, $n=2)$, Asian brown flycatcher (Muscicapa dauurica, $n=2$ ), golden-bellied gerygone (Gerygone sulphurea, $n=1)$, sunbird sp. Nectariniidae $(n=1)$, Siberian thrush (Geokichla sibirica, $n=1$ ), blue whistling-thrush (Myophonus caeruleus, $n=1$ ), plaintive cuckoo (Cacomantis merulinus, $n=2$ ), chestnut-breasted malkoha (Phaenicophaeus curvirostris, $n=1$ ), Javan kingfisher (Halcyon cyanoventris, $n=43$ ), Javan frogmouth (Batrachostomus javensis, $n=12$ ), freckle-breasted woodpecker (Dendrocopos analis, $n=2)$, sooty-headed bulbul (Pycnonotus aurigaster, $n=29$ ), Sunda cuckoo (Cuculus Lepidus, $n=3$ ) and collared scops owl (Otus lempiji, $n=32$ ). At least three species of bats perched on the bridges, of which we could only identify one species, the greater short-nosed fruit bat (Cynopterus sphinx, $n=6)$.

Table 1. Number of crossings of mammals per each bridge in the agroforestry habitat at Cipaganti, West Java, revealed via camera traps. We report the sampling effort (in days) on each bridge, the mean height where the bridges were fixed to trees, and the length of the bridge.

\begin{tabular}{|c|c|c|c|c|c|c|c|}
\hline \multirow[b]{2}{*}{ Bridge } & \multirow{2}{*}{$\begin{array}{l}\text { Days of } \\
\text { Monitoring }\end{array}$} & \multirow{2}{*}{$\begin{array}{c}\text { Mean } \\
\text { Height (m) }\end{array}$} & \multirow{2}{*}{$\begin{array}{l}\text { Length } \\
\text { (m) }\end{array}$} & \multicolumn{4}{|c|}{ Crossings } \\
\hline & & & & $\begin{array}{c}\text { Javan Slow } \\
\text { Loris }\end{array}$ & $\begin{array}{l}\text { Javan Palm } \\
\text { Civet }\end{array}$ & $\begin{array}{c}\text { Other } \\
\text { Mammals }\end{array}$ & Total \\
\hline Waterline 1 & 312 & 4.0 & 17.4 & 132 & 257 & 64 & 453 \\
\hline Waterline 2 & 294 & 3.8 & 51.3 & 283 & 214 & 60 & 557 \\
\hline Waterline 3 & 209 & 5.0 & 72.3 & 118 & 29 & 3 & 150 \\
\hline Waterline 4 & 271 & 7.0 & 74.5 & 266 & 218 & 56 & 540 \\
\hline Waterline 5 & 290 & 3.0 & 74.0 & 280 & 220 & 62 & 562 \\
\hline Rubber 1 & 276 & 5.5 & 54.9 & 108 & 0 & 9 & 117 \\
\hline Rubber 2 & 87 & 3.5 & 18.4 & 19 & 0 & 0 & 19 \\
\hline Rubber 3 & 266 & 4.0 & 13.7 & 153 & 0 & 1 & 154 \\
\hline Rubber 4 & 113 & 4.5 & 14.3 & 58 & 0 & 0 & 58 \\
\hline Rubber 5 & 88 & 5.5 & 13.9 & 20 & 0 & 5 & 25 \\
\hline
\end{tabular}

\section{Discussion}

We found that bridges were effective in providing connectivity and perching for at least 19 mammal and avian species in an agroforestry habitat. We also found that camera traps were efficient in monitoring use of artificial bridges (and for slow lorises, identity of the individuals [11]). The two most abundant arboreal mammals in the agroforest environment of Cipaganti, the Javan slow loris and the Javan palm civet, habituated to the bridges quickly and used them regularly. Five mammals are known to be present at low densities in the area but did not use bridges [7]. We expected the binturong and the banded linsang to use the bridges as they are tree-dwelling, but it is possible that these species are restricted to higher elevations in the study area that retain more forest. In a 2014 study in the agroforest habitat, they occurred at low densities [7]. Use of simple and reasonably priced local supplies and agreement over maintenance of bridges with farmers meant that as of July 2020, all 12 active bridges were still standing. We agree with Gregory et al., 2017 the success of implementation of artificial bridges links to several factors including infrastructure, bridge type and benefits to the community and other wildlife [10]. The success of this conservation intervention may also be linked to how well the species are integrated with surrounding habitats [18].

Bridge type was important in our intervention [10], with only slow lorises and tree shrews using the smaller and more flexible rubber bridges. The lack of use of these bridges by other taxa, including civets that frequently used the waterline bridges, is most likely due to the lack of stability provided by the substrate. Because of their low center of gravity, elongated fingers with membranes and long tails that enhance the civet's stability when crossing unstable and thin substrates including telephone cables, powerlines, raised wires and ropes [16], we expected that civets also would be able to use the rubber bridges. The slow lorises are more equipped to use the rubber bridges due to their ability to grasp smaller objects with their hands [11]. Since the rubber bridges are substantially cheaper, it would be worth investigating rubber of a larger size and stability to accommodate larger arboreal species 
like the civets. At the same time, the usefulness of the waterline bridges to farmers meant that they were an important mechanism to provide an interface between the needs of wildlife and of the local community. These costs should be considered when planning an intervention of this nature.

Camera traps proved successful and cost effective in allowing us to identify species and individuals [19]. We initially hoped to use passthrough microchip readers to monitor slow loris use of bridges, but our infrastructure was not suitable. Through camera trap use, we could identify at least 19 species using the bridges (c.f. [20]). One of the challenges of camera traps was the risk of poor or partial images, meaning more species might have used the bridges than were recorded, as well as the behavior of wildlife potentially being influenced by the camera traps meaning some species may have avoided bridges [21]. For small conservation projects with lower budgets, however, we feel this method is highly practical.

\section{Conclusions}

We have shown the use of the bridges by different species, but further research is still needed to show if the implementation has helped mitigate the effects of fragmentation. We have already shown that the bridges positively affect Javan slow lorises by providing connectedness to habitats that had not been previously used, reduced their time on the ground, and increased foraging opportunities [11]. Therefore, we will continue to monitor the impact of bridge use on other wildlife. We conclude that the bridges we have implemented, and the monitoring undertaken so far, have been successful at benefiting arboreal mammal and bird species by providing a safe point for crossing or perching. Including and considering the needs of local farmers in our initiative has been vital, and their knowledge also helped us to develop the most cost effective and long-lasting bridges. We highly suggest implementing bridges in fragmented areas and their continued monitoring, so that we can further understand the benefits that these bridges provide wildlife.

Author Contributions: Conceptualization: K.A.I.N.; Methodology: K.A.I.N., V.H., M.C., H.B., K.H. and J.E.; Formal Analysis: V.H. and M.C.; Investigation: M.C., H.B. and K.H.; Data Curation: K.A.I.N., M.C., H.B. and K.H.; Writing-Original Draft Preparation: K.A.I.N. and V.H.; Writing-Review and Editing: M.C., H.B., K.H., J.E. and M.A.I.; Supervision: K.A.I.N., M.C. and M.A.I.; Project Administration: K.A.I.N.; Funding Acquisition: K.A.I.N. All authors have read and agreed to the published version of the manuscript.

Funding: This research was funded by Amersfoort Zoo, Augsburg Zoo, Brevard Zoo, Cleveland Zoo and Zoo Society, Columbus Zoo and Aquarium, Cotswolds Wildlife Park, Disney Worldwide Conservation Fund, Ernst Kleinwald Foundation, Global Challenges Fund, Henry Doorly Zoo, International Primate Protection League, Lee Richardson Zoo, Little Fireface Project, Mohamed bin al Zayed Species Conservation Fund (152511813), Margot Marsh Biodiversity Fund, Marjorie Coote Foundation, Memphis Zoo, Moody Gardens Zoo, National Geographic (GEFNE101-13), Naturzoo Rhein, Paradise Wildlife Park, People's Trust for Endangered Species, Phoenix Zoo, Primate Action Fund, Sacramento Zoo, Shaldon Wildlife Trust, Sophie Danforth Conservation Biology Fund, and ZGAP.

Acknowledgments: We would like to thank Indonesian RISTEK (386/SIP/FRP/E5/Dit.KI/XI/2017, S/476/E5/E5.4/ SIP/2020) and the regional Perhutani and BKSDA for authorizing this study. Thank you to the field team at Little Fireface Project and Pak Amank for producing the technical drawings.

Conflicts of Interest: The authors declare no conflict of interest. The funders had no role in the design of the study; in the collection, analyses, or interpretation of data; in the writing of the manuscript, or in the decision to publish the results.

\section{References}

1. Busch, J.; Ferretti-Gallon, K. What drives deforestation and what stops it? A meta-analysis. Rev. Environ. Econ. Policy. 2017, 11, 3-23. [CrossRef]

2. Dixo, M.; Metzger, J.P.; Morgante, J.S.; Zamudio, K.R. Habitat fragmentation reduces genetic diversity and connectivity among toad populations in the Brazilian Atlantic Coastal Forest. Biol. Conserv. 2009, 142, 1560-1569. [CrossRef]

3. Taylor, A.C.; Walker, F.M.; Goldingay, R.L.; Ball, T.; Van Der Ree, R. Degree of landscape fragmentation influences genetic isolation among populations of a gliding mammal. PLoS ONE 2011, 6, 26651. [CrossRef] [PubMed] 
4. Yokochi, K.; Chambers, B.K.; Bencini, R. An artificial waterway and road restrict movements and alter home ranges of endangered arboreal marsupial. J. Mammal. 2015, 96, 1284-1294. [CrossRef]

5. Cappa, F.M.; Borghi, C.E.; Giannoni, S.M. How roads affect the spatial use of the guanaco in a South American protected area: Human connectivity vs animal welfare. Diversity 2019, 11, 110. [CrossRef]

6. Austin, K.G.; Schwantes, A.; Gu, Y.; Kasibhatla, P.S. What causes deforestation in Indonesia? Environ. Res. Lett. 2019, 14, 024007. [CrossRef]

7. Rode-Margono, E.J.; Voskamp, A.; Spaan, D.; Lehtinen, J.K.; Roberts, P.D.; Nijman, V.; Nekaris, K.A.I. Records of small carnivores and of medium-sized nocturnal mammals on Java, Indonesia. Small Carniv. Conserv. 2014, 50, 1-11.

8. Sunderlin, W.D.; Resosudarmo, I.A.P. The effect of population and migration on forest cover in Indonesia. J. Environ. Dev. 1999, 8, 152-169. [CrossRef]

9. Nekaris, K.A.I.; Poindexter, S.; Reinhardt, K.D.; Siguad, M.; Cabana, F.; Wirdateti, W.; Nijman, V. Coexistence between Javan slow lorises (Nycticebus javanicus) and humans in a dynamic agroforestry landscape in West Java, Indonesia. Int. J. Primatol. 2017, 38, 303-320. [CrossRef]

10. Gregory, T.; Carrasco-Rueda, F.; Alonso, A.; Kolowski, J.; Diechmann, J.L. Natural canopy bridges effectively mitigate tropical forest fragmentation for arboreal mammals. Sci. Rep. 2017, 7, 3892. [CrossRef] [PubMed]

11. Birot, H.; Campera, M.; Imron, M.A.; Nekaris, K.A.I. Artificial canopy bridges improve connectivity in fragmented landscapes: The case of Javan slow lorises in an agroforest environment. Am. J. Primat. 2020, 82, 23076. [CrossRef] [PubMed]

12. Scales, B.R.; Marsden, S.J. Biodiversity in small-scale tropical agroforests: A review of species richness and abundance shifts and the factors influencing them. Environ. Conserv. 2008, 35, 160-172. [CrossRef]

13. Yokochi, K.; Bencini, R. A remarkably quick habituation and high use of a rope bridge by an endangered marsupial, the western ringtail possum. Nat. Conserv. 2015, 11, 79-94. [CrossRef]

14. Goldingay, R.L.; Taylor, B.D. Can field trials improve the design of road-crossing structures for gliding mammals? Ecol. Res. 2017, 32, 743-749. [CrossRef]

15. Balbuena, D.; Alonso, A.; Panta, M.; Garcia, A.; Gregory, T. Mitigating tropical forest fragmentation with natural and semi-artificial canopy bridges. Diversity 2019, 11, 66. [CrossRef]

16. Spaan, D.; Williams, M.; Wirdateti, W.; Semiadi, G.; Nekaris, K.A.I. Use of raised plastic water-pipes by common palm civet Paradoxurus hermaphroditus for habitat connectivity in an anthropogenic environment in West Java, Indonesia. Small Carniv. Conserv. 2014, 51, 85-87.

17. Veron, G.; Patou, M.L.; Tóth, M.; Goonatilake, M.; Jennings, A.P. How many species of Paradoxurus civets are there? New insights from India and Sri Lanka. J. Zool. Syst. Evol. Res. 2015, 53, 161-174. [CrossRef]

18. Weston, N.; Goosem, M.; Marsh, H.; Cohen, M.; Wilson, R. Using canopy bridges to link habitat for arboreal mammals: Successful trials in the Wet Tropics of Queensland. Aust. Mammal. 2011, 33, 93-105. [CrossRef]

19. Hardy, A.; Clevenger, A.P.; Huijser, M.; Neale, G. An overview of methods and approaches for evaluating the effectiveness of wildlife crossing structures: Emphasizing the science in applied science. In Proceedings of the 2003 USA International Conference on Ecology and Transportation, New York, NY, USA, 24-29 August 2003; Irwin, C.L., Garrett, P., McDermott, K.P., Eds.; Center for Transportation and the Environment: Raleigh, NC, USA, 2003; pp. 319-330.

20. Evans, M.N.; Vickers, S.H.; Abu-Bakar, M.S.; Goossens, B. Small carnivores of the Lower Kinabatangan wildlife sanctuary, Sabah, Borneo, including a new locality for the otter civet Cynogale bennetti. Small Carniv. Conserv. 2016, 54, 26-38.

21. Meek, P.D.; Ballard, G.; Fleming, P.J.S. The pitfalls of wildlife camera trapping as a survey tool in Australia. Aust. Mammal. 2015, 37, 13-22. [CrossRef]

Publisher's Note: MDPI stays neutral with regard to jurisdictional claims in published maps and institutional affiliations. 